\title{
Indonesian Adaptation of Entrepreneurial Self-Efficacy Scale
}

\author{
Aftina Nurul Husna ${ }^{1 *}$, Nur Akmal ${ }^{2}$ \\ ${ }^{1}$ Faculty of Psychology and Humanities, Universitas Muhammadiyah Magelang, Magelang, Indonesia \\ ${ }^{2}$ Faculty of Medicine, Universitas Negeri Makassar, Makassar, Indonesia \\ *Corresponding author. Email: anhusna@ummgl.ac.id
}

\begin{abstract}
Entrepreneurial self-efficacy (ESE) is a crucial psychological variable intensively studied in Indonesia entrepreneurship research. However, it lacks of reliable and valid instrument to measure the construct. This research aims to adapt Entrepreneurial Self-Efficacy Scale (ESES) into Bahasa Indonesia and to test its psychometric properties for Indonesian use. After being translated, the scale was administered to 551 university students from Magelang and Makassar. The result of reliability analysis showed excellent reliability and examination of construct validity using CFA indicates good model fit. ESE significantly correlates with hope of success aspect of achievement motive, openness to experience, entrepreneurial intention, and entrepreneurial characters. Implications of this scale for further research and entrepreneurial education are discussed.
\end{abstract}

Keywords: entrepreneurial self-efficacy, Entrepreneurial Self-Efficacy Scale (ESES), scale adaptation,

\section{Indonesian context}

\section{INTRODUCTION}

Having self-efficacy to start a business is among salient characteristics of potential entrepreneurs. This quality is crucial because entrepreneurship involves personal intention and planned actions, and a person needs to have a mindset that he/she is confident toward his/her ability to execute the actions [1]. The notion of entrepreneurial selfefficacy is thus coined to explain phenomenon of individual belief in personal capability to perform roles and tasks that are related to entrepreneurial activity and aimed to achieve entrepreneurial outcomes [2]. It is derived from theory of perceived self-efficacy conceptualized by Bandura [3], [4]. Bandura [3] explained that self-efficacy is "judgments of how well one can execute courses of action required to deal with prospective situations." Efficacy in dealing with a situation is more than knowing what to do. It involves a capability to organize one's cognitive, social, and behavioural skills into an integrated action to achieve purposes. According to Bandura [3], people usually avoid activities that they believe exceed their coping capabilities. However, they will undertake activities that they believe themselves capable of managing assuredly. Efficacy judgments thus determine how much effort they will expend and how long they will persist when facing difficulties. People who doubt their capabilities would easily give up and slacken their efforts, meanwhile those who have strong self-efficacy would exert more effort to face challenges and perseverance.

Self-efficacy judgments determine human functioning through their impact on choice behaviour, effort expenditure, and emotional reactions to demands [4]. In life, people would have to deal with changing environment consisting of uncertainties and unpredictable events. According to Bandura [4], lack of belief in personal capabilities leads people to approach difficult situations anxiously because of expected fear. This mental disruption may lower their ability to perform well. People with selfefficacy are more confident and anticipate adversities as challenges to be mastered. They expect for success, a favourable or satisfactory result.

Self-efficacy is widely known as a strong cognitive determinant of motivation and performance in work [5]. In entrepreneurship context, the importance of self-efficacy or entrepreneurial self-efficacy (ESE) drives intensive studies in the last two decades. ESE may explain why some people avoid engaging in entrepreneurial activity [6]. ESE is mediating factor for entrepreneurial intention development on young people with prior entrepreneurial experience [7]. ESE is influenced by one's prior work and leadership experience, entrepreneurial education or training, and the presence of entrepreneurial role models as well as business mentors [8], [9]. ESE can predict firm performance [10], [11] and entrepreneurial intention while the relationship is influenced by national individualistic or collectivistic culture [12].

In Indonesia, ESE is considered favourite research variable for academicians and students especially in relations to entrepreneurial intention and entrepreneurial educations [13]-[15]. Despite of intensive research, there is a lack of information in the literatures regarding the various instruments used to measure ESE as a psychological attribute. Its conceptualization and psychometric qualities, such as reliability and validity of the instruments, are also unknown. It might indicate that instrument development, especially in form of psychological scale, hardly becomes concern of Indonesian researchers. In contrast with this situation, psychological scales to measure ESE have 
actually been developed by researchers abroad [6], [7], [16]. These scales are thus valuable to be examined, to enrich understanding about ESE in Indonesian context.

Based on practical problems observed above, this research aims to adapt Entrepreneurial Self-Efficacy Scale (ESES) developed by McGee et al [16] into Bahasa Indonesia. As the newest scale developed to measure ESE, this scale has well-reported theoretical conceptualization based on long study of ESE, information about items consisting the scale, and results of psychometric analysis based on empirical data from various samples.

McGee et al [16] defined ESE as degree of a one's confidence in his/her ability to do specific tasks in four phases of a venture creation process: searching, planning, marshalling, and implementing. Searching is a phase where a person develops unique business idea and identifies business opportunity. Planning is where a person transforms business idea into workable business plan. Marshalling is when a person later gathers resources to create a business in reality, such as capital, labour, costumers, and supplies. Finally, implementing involves actions to grow the business and sustain it by applying management skill and principles to manage people and finance.

ESES is considered more refined measure of ESE. ESES has 19 items and is responded using Likert scale ranging from 1 (very little) to 5 (very much) on how confidence a person has in his/her ability to engage in entrepreneurial tasks in each phase [16]. Adapting ESES for Indonesian use has several practical advantages. It reduces costs and time to develop a completely new scale, even though it is possible to do, and it will enables cross-cultural study about ESE using a considered same instrument in the future. Additionally, it will open new area of study in Indonesia, not only about ESE but also psychological scale development to measure important psychological variables in entrepreneurship study.

This research adapts Entrepreneurial Self-Efficacy Scale (ESES) by two means: translating the scale from English to Bahasa Indonesia and adjusting some Western cultural expressions found in the items of the original version to be suitable for Indonesian subjects. The adaptation follows procedures of psychological scale adaptation delineated by Geisinger [17] and Gudmundsson [18] and applied backtranslation method [19] to ensure equivalence in meanings and word choices in the target language. After translation, empirical data are collected to test psychometric properties of the scale. Questions to be answered by this research are: How well are the reliability and construct validity of Indonesian version of ESES?

\section{RESEARCH METHOD}

\subsection{Instrument Adaptation}

This process involved six people. First, two psychologists proficient in English translated the scale separately and produced two early drafts of Indonesian version of ESES. Later, one moderator evaluated the drafts from previous phase by comparing the word choices and its fitness and making consensus for the best translation. The second more refined draft was thus given to one professional translator with no background and experience in psychology and scale development to do back-translation. Indonesian version of ESES was retranslated to English and the result was later given to the moderator to be compared again with the original version. The moderator examined similarity and equivalence for both scales and made some correction in Indonesian version if there are significant differences. Finally, the final draft of Indonesian version of ESES was given to two university students to check its readability. In general, above process went without significant difficulties. The original version itself uses everyday language without any idiom so that it is easily translated. The general opening question "How much confidence do you have in your ability to...?" was translated to "Seberapa besar kamu yakin pada kemampuanmu untuk...?" The list of items of Indonesian version of ESES are presented in Appendix A.

Translation of few items took more consideration. For example, "brainstorm a new idea" is translated to "memunculkan ide baru" even though a brainstorming implies more meaning involving an exchange of spontaneous thoughts in a discussion with others. Marketing/ advertising campaign is translated to "strategi pemasaran/ iklan" because in Indonesia, a campaign has political connotation in the mind of common people. "Kampanye pemasaran" is sometimes used but as a business technical term, not an everyday language. "Get others to identify with" is translated to "mendapatkan orang-orang dengan ide yang sama", as close as possible to its original meaning as an English idiom meaning "to feel that you are similar to someone and can understand them or their situation" (Cambridge Dictionary). Bahasa Indonesia has a loan word "identifikasi", but it is used in different way.

\subsection{Measurements}

Indonesian version of ESES construct validity is proven by correlating it with several variables. In this study, the scale is correlated with achievement motives, Big Five personality, individual entrepreneurial intent, and entrepreneurial characters.

Achievement Motives. Achievement motives are reasons that motivate a person to behave and to keep up with standards of excellence. It is measured using 10-items of Achievement Motives Scale by Lang and Fries [20] which had been adapted into Bahasa Indonesia by Husna and Akmal [21]. AMS consists of two factors: hope for success (item example: "saya menikmati situasi di mana saya dapat menggunakan kemampuan saya") and fear of failure ("saya merasa tak tenang melakukan sesuatu jika saya tidak yakin berhasil"). Participants responded to the items on 4-point Likert scale ranging from 1 (strongly disagree) to 4 (strongly agree).

Big Five Personality. Big Five personality is a theory of human personality described by five dimensions of personality: extraversion, agreeableness, conscientiousness, neuroticism, and openness to experience. Big five personality has been found to be related to entrepreneurial 
variables such as entrepreneurial intention and performance [22]. Big Five personality is measured using Big Five Inventory adapted to Indonesian use by Ramdhani [23] specifically in dimensions of openness to experience (for example: "saya adalah orang yang sering dapat ide baru") and neuroticism ("saya adalah orang yang mudah gugup"). Participants responded to the items on 5-point Likert scale ranging from 1 (strongly disagree) to 5 (strongly agree). Individual Entrepreneurial Intent. Individual entrepreneurial intent is measured using the scale developed by Thompson [24]. Individual Entrepreneurial intent is an intention to launch a business with conscious plan in mind to do the necessary actions. Individual Entrepreneurial Intent Scale is a one dimensional scale consisting of 10 items. Entrepreneurial intent is assessed by asking the presence of intention or plan to start a business, learning about starting a business, effort to search business opportunity, and active effort to gather resources. Participants responded to the items on 6-point Likert scales ranging from 1 (very untrue) to 6 (very true).

Entrepreneurial Characters. Entrepreneurial characters are personal qualities indicating a person's capacity and suitability to engage in entrepreneurial activity. This variable is measured using revised version of Skala Karakter Wirausaha/ SK-Wira developed by Husna, Zahra, and Haq [25] consisting of 23 items. This scale is multidimensional scale with correlated dimensions: achievement motivation (item example: "saya mencari cara agar tugas dapat selesai dengan hasil yang sempurna"), innovativeness ("saya senang jika masyarakat berinovasi"), autonomy ("saya berani berpendapat untuk mempertahankan pilihan pribadi”), and risk-taking ("sebelum paham untung-ruginya, saya menahan diri dari membuat keputusan"). Participants responded to the items on 5-point Likert scales ranging from 1 (strongly disagree) to 5 (strongly agree).

\subsection{Participants and Procedure}

Data were collected during March-May 2019. First, in pilot study to try out the instruments, data were collected from 81 university students (aged 17-24 years old) in Magelang (49\%) and Makassar (51\%). Later, after ensuring the psychometric qualities of the instruments, 598 university students in Magelang, Central Java (49.8\%) and Makassar, South Sulawesi $(50.2 \%)$ were recruited to take the survey, but only 551 questionnaires were completely returned (Sample 2). In term of gender, $48.2 \%$ of them are female and $35.6 \%$ have already business experience. Samples were chosen conveniently considering accessibility in the field and limited resources.

In order to reach optimum possible representations, the participants were included from various faculties in the universities where both researchers work: health science, law science, engineering, Islamic studies, educational science, business and economics, psychology, and medicine. The scale was administered in groups with the help of several research assistants entering appointed classes where the participants attend. Before answering the questionnaire, participants were explained the purpose, procedure, and duration by the assistants. Their identity and responses were kept confidential and they got a pen as reward for their participation. The data were analyzed using SPSS for analyzing reliability and correlates of entrepreneurial self-efficacy, and MPlus for running Confirmatory Factor Analysis (CFA).

\section{RESULTS AND DISCUSSION}

A reliable and valid instrument means that the instrument has ability to produce consistent results and to measure the intended construct [26]. To be reliable and valid, an instrument should meet some indicators. First, scale reliability is tested using internal consistency method involving inter-item correlations. Good internal consistency is indicated by Cronbach's alpha $(\alpha)$ coefficient equal or greater than 0.08 and the scale consists of items with itemtotal correlation higher than 0.3 . Second, scale validity is proven by two means: examining the scale internal structure using CFA and correlation with other variables. Between entrepreneurial self-efficacy and its correlates, the association should be statistically significant to prove concurrent and predictive validity[26].

\subsection{Internal Consistency}

Cronbach's alpha coefficient $(\alpha)$ for the all items of Indonesian version of ESES is 0.939. Cronbach's $\alpha$ value of each subscales range from 0.788 to 0.890 (see Table I). Evaluating the items, all items have item-total correlation values more than 0.30 . All values indicate that the scale has good internal consistency. Dimension marshalling has slightly lower $\alpha$ but it is considered acceptable.

Table 1 Internal Consistency for Indonesian ESES

\begin{tabular}{|l|r|r|r|r|r|r|}
\hline $\begin{array}{c}\text { Mean } \\
\text { \& SD }\end{array}$ & All & $\boldsymbol{S}$ & $\boldsymbol{P}$ & $\boldsymbol{M}$ & $\boldsymbol{I P}$ & $\boldsymbol{I F}$ \\
\hline Items & $\begin{array}{r}3.88 \\
(0.71)\end{array}$ & $\begin{array}{r}3.76 \\
(0.65)\end{array}$ & $\begin{array}{r}3.84 \\
(0.68)\end{array}$ & $\begin{array}{r}3.86 \\
(0.71)\end{array}$ & $\begin{array}{r}3.87 \\
(0.74)\end{array}$ & $\begin{array}{r}4.07 \\
(0.75)\end{array}$ \\
\hline Scale & $\begin{array}{r}73.71 \\
(11)\end{array}$ & $\begin{array}{r}11.29 \\
(2.0)\end{array}$ & $\begin{array}{r}15.36 \\
(2.7)\end{array}$ & $\begin{array}{r}11.59 \\
(2.1)\end{array}$ & $\begin{array}{r}23.24 \\
(3.9)\end{array}$ & $\begin{array}{r}12.21 \\
(2.3)\end{array}$ \\
\hline $\boldsymbol{\alpha}$ & 0.939 & 0.813 & 0.853 & 0.788 & 0.864 & 0.890 \\
\hline
\end{tabular}

Abbreviations: $\mathrm{M}$, mean; s2, variance; $\mathrm{s}$, standard deviation; ESES, Indonesian version of Entrepreneurial Self-Efficacy Scale; S, searching (dimension 1); $\mathrm{P}$, planning (dimension 2); $\mathrm{M}$, marshalling (dimension 3); IP, implementing on people (dimension 4); IF, implementing on finance (dimension 5).

\subsection{Construct Validity}

The results of CFA of Indonesian version of ESES considerably indicate good fit based on criteria of model fit [27], [28]. The results are reported in Table 2. 
Table 2 CFA Results for Indonesian Version of ESES

\begin{tabular}{|l|l|l|}
\hline \multicolumn{1}{|c|}{ Index } & \multicolumn{1}{c|}{ Obtained Values } & \multicolumn{1}{c|}{ Criteria } \\
\hline $\boldsymbol{\chi}^{\mathbf{2}}$ & $575.630(\mathrm{p}<0.00)$ & $\mathrm{p}>0.05$ \\
\hline $\boldsymbol{\chi}^{\mathbf{2}} / \mathrm{df}$ & $575.630 / 147$ & $2: 1$ or $3: 1$ \\
\hline TLI & 0.918 & $\geq 0.90$ or 0.95 \\
\hline CFI & 0.930 & $\geq 0.90$ or 0.95 \\
\hline RMSEA & 0.073 & $<0.08$ \\
\hline SRMR & 0.051 & $<0.08$ \\
\hline
\end{tabular}

Abbreviations: $\chi 2=$ Chi-square; $\chi 2 / \mathrm{df}=$ Chi-square/degree of freedom; RMSEA = Root Mean Square Error of Approximation; $\mathrm{CFI}=$ Comparative Fit Index; TLI = Tucker-Lewis Index; SRMR = Standardized Root Mean Square Residual

The values of $\chi^{2}$ and $\chi 2 / \mathrm{df}$ obtained are apparently higher than the criteria and thus indicate poor model fit. Kenny (2015) explained that the values of $\chi 2$ is affected by sample size so that it is actually not preferable for a study with big sample size ( $>400$ cases) because the results would always be statistically significant. Based on this, we examine the results of other indicators which are greater than the criteria and thus the model is considered good fit. The correlations between factors based on standardized estimates can be seen in a diagram below (Figure 1). As noted in the figure, $\mathrm{y}$ is item (1 until 19); $\mathrm{f}$ is factor or dimension. $\mathrm{F} 1$ is dimension 1, searching, and so on until F5, dimension 5, implementing on finance. All factors show significant high correlations in which dimension 3, marshalling, shows the highest estimate.

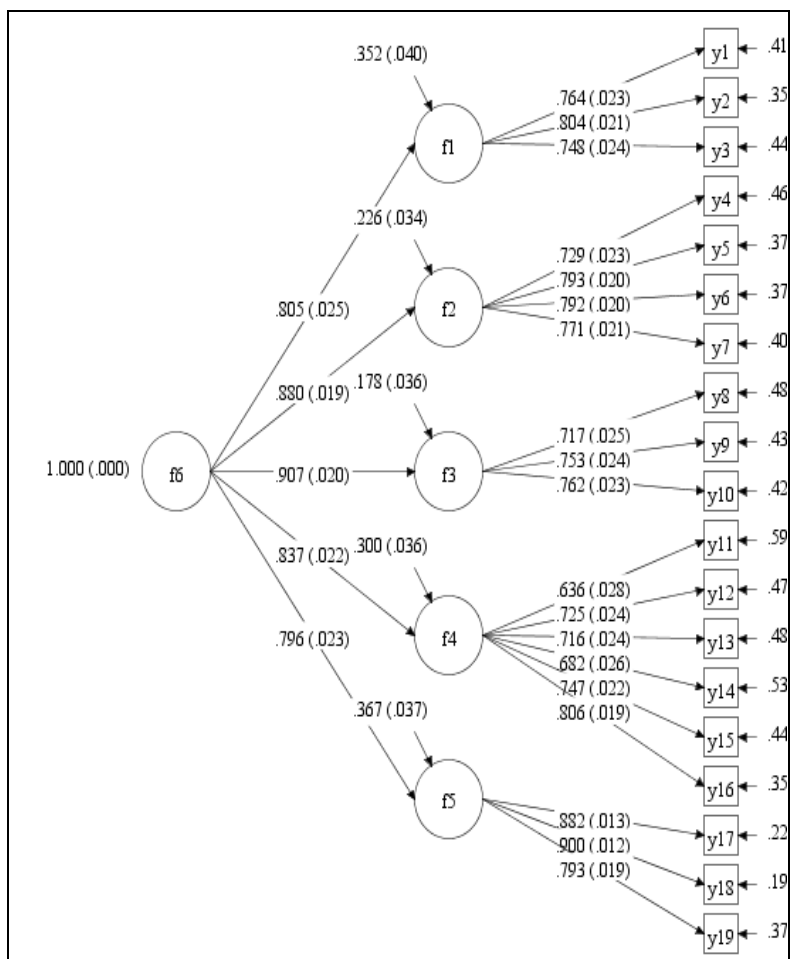

Figure 1 Correlations of Factors Obtained

\subsection{Correlates of ESE}

Entrepreneurial self-efficacy measured by Indonesian version of ESES shows significant correlations with several variables. Overall results are presented in Table 3 below.

Table 3 Matrix of Correlates of Entrepreneurial Self-Efficacy

\begin{tabular}{|c|c|c|c|c|c|c|c|c|c|c|c|c|}
\hline & ESE & $\mathbf{A M}$ & HS & FF & EC & I & AMV & A & RT & IEI & OE & $\mathbf{N}$ \\
\hline ESE & 1 & .008 & $.098^{*}$ & -.065 & $.286^{* *}$ & $.265^{* *}$ & $.253^{* *}$ & $.220^{* *}$ & $.202^{* *}$ & $.336^{* *}$ & $.195^{* *}$ & -.048 \\
\hline AM & & 1 & $.822^{* *}$ & $.895^{* *}$ & $.160^{* *}$ & $.151^{* *}$ & $.192^{* *}$ & .023 & $.170^{* *}$ & $-.190^{* *}$ & $.126^{* *}$ & $.314^{* *}$ \\
\hline HS & & & 1 & $.482^{* *}$ & $.291^{* *}$ & $.299^{* *}$ & $.294^{* *}$ & $.108^{*}$ & $.258^{* *}$ & -.058 & $.230^{* *}$ & .026 \\
\hline FF & & & & 1 & .019 & -.002 & .065 & -.049 & .059 & $-.247^{* *}$ & .013 & $.463^{* *}$ \\
\hline $\mathrm{EC}$ & & & & & 1 & $.836^{* *}$ & $.850^{* *}$ & $.770^{* *}$ & $.838^{* *}$ & $.382^{* *}$ & $.502^{* *}$ & $-.087^{*}$ \\
\hline I & & & & & & 1 & $.616^{* *}$ & $.462^{* *}$ & $.615^{* *}$ & $.400^{* *}$ & $.412^{* *}$ & $-.088^{*}$ \\
\hline AMV & & & & & & & 1 & $.590^{* * *}$ & $.653^{* *}$ & $.313^{* *}$ & $.439^{* *}$ & -.043 \\
\hline A & & & & & & & & 1 & $.495^{* *}$ & $.277^{* *}$ & $.376^{* *}$ & $-.101^{*}$ \\
\hline
\end{tabular}

a.Abbreviations: ESE, entrepreneurial self-efficacy; AM, achievement motives; HS, hope of success (aspect 1 of AM); FF, fear of failure (aspect 2 of AM); EC, entrepreneurial characters; I, innovativeness (aspect 1 of EC); AMV, achievement motivation (aspect 2 of EC); A, autonomy (aspect 3 of EC); RT, risk taking (aspect 4 of EC); IEI, individual entrepreneurial intent; OE, openness to experience; N, neuroticism; * statistically significant at $\mathrm{p}<0.05 ; * *$ statistically significant at $\mathrm{p}<0.01$

ESE is not correlated with all achievement motives (AM). Detailed examination to its aspects separately, ESE has significant correlation with hope of success $(r=0.098$, $p<0.05$ ). Rather than fear of failure, entrepreneurial selfefficacy is more connected with the hope of success of a person.

ESE is correlated with entrepreneurial characters/EC ( $\mathrm{r}=$ $0.286, \mathrm{p}<0.01)$ and all of its aspects. The higher a person's entrepreneurial characters in him/her, the higher his/her entrepreneurial self-efficacy. The highest correlation is found between ESE and innovativeness aspect of EC ( $\mathrm{r}=$ $0.265, \mathrm{p}<0.01)$. It is understandable because aspect of searching and planning for a business in ESE have some degree of innovativeness. ESE is correlated with achievement motivation $(\mathrm{r}=0.253, \mathrm{p}<0.01)$, autonomy $(\mathrm{r}=$ $0.220, p<0.01)$, and risk taking $(r=0.202, p<0.01)$.

ESE is significantly correlated with individual entrepreneurial intention/ IEI $(r=0.336, p<0.01)$. As a person's have more confidence about his/her ability to do business, he/ she is more likely to start a business. 
ESE is only significantly correlated with openness aspect of Big Five personality $(\mathrm{r}=0.195, \mathrm{p}<0.01)$. It goes as predicted; to do a business a person needs to have innovation and courage to face uncertainty. This capacity is difficult to achieve without a personal disposition toward new experiences and stable emotion.

\subsection{Discussions}

Result of data analyses show that Indonesian ESES has good reliability and validity. The overall adapted scale has good internal consistency indicated by Cronbach's $\alpha$ value that is greater than 0.9. Only in dimension marshalling, alpha value is lower than 0.8 and still considered acceptable. The scale also has good internal structure as confirmed with CFA. Result of CFA shows good model fit and it support the model of 19-item ESES developed by McGee et al [16]. Minimum content discrepancy between items in original ESES and items in Indonesian version of ESES explains fairly similar results regarding psychometric qualities. The original scale items are relatively easy to be translated into Bahasa Indonesia. There are only minimal cultural expressions in the original version and the word choices are easy to understand for their equivalences in Bahasa Indonesia. These factors contribute in good adaptation process as stated by Cha, Kim, and Erlen [19] because scale adaptation must be able to translate both literal and cultural aspects of the scale.

ESE measured with Indonesian ESES confirms result from previous researches. ESE significantly correlates with entrepreneurial intention [12], [29], [30]. Correlations with entrepreneurial characters (achievement motivation, innovativeness, autonomy, and risk-taking), achievement motives, and openness to experience aspect of Big Five personality are considered new findings in Indonesian context. It is found that the higher one's entrepreneurial self-efficacy, the higher his/ her personal qualities regarding entrepreneurial characters. However, this correlation is not clear-cut, and its causal relationship needs to be examined again. Regarding achievement motives, ESE only correlates with hope of success and it confirms Kirsch in Bandura [4] that people with higher self-efficacy tend to expect success. This quality leads entrepreneurs to be more persistent in achieving business targets and utilizing opportunities.

Results of psychometric analysis prove that Indonesian version of ESES is considered reliable and valid psychological scale to measure ESE. This scale can be used for future research to measure entrepreneurial self-efficacy. Despite of considerably good psychometrical results, this scale may need improvement in term of sample characteristic variation. This study used homogenous sample of university students and it did not have reliable data from entrepreneurs or other possible groups of sample based on ethnicity, gender, age, region, and religion. These demographical characteristics may be influential because there are phenomena in Indonesian society to stereotype certain ethnic groups to have more entrepreneurial spirit and skill than other. Discrepancy between Indonesian urban and rural area is quite high too and it causes innovative business activities are more concentrated in big cities. These factors should be taken into account to test this scale applicability and generalizability.

\section{CONCLUSIONS AND IMPLICATIONS}

Indonesian version of Entrepreneurial Self-Efficacy Scale is considered reliable and valid to measure entrepreneurial self-efficacy. It has practical benefit for future research to test more complex hypothetical model related with entrepreneurial self-efficacy. It can be used in the context of entrepreneurial education to assess young people who are potential entrepreneurs. This scale can be used to identify which aspects of entrepreneurial tasks a person is still lacking and suggest more accurate recommendation to educator, trainer, or other stakeholder to prepare materials for entrepreneurial learning.

\section{ACKNOWLEDGMENT}

This report is part of a project on developing entrepreneurial characteristic scale. This project was funded by Universitas Muhammadiyah Magelang year 2018.

\section{REFERENCES}

[1] N. F. Krueger, Jr. and D. V. Brazeal, "Entrepreneurial Potential and Potential Entrepreneurs," Entrep. Theory Pract., vol. 18, no. 3, pp. 91-104, 1994.

[2] A. Newman, M. Obschonka, S. Schwarz, M. Cohen, and I. Nielsen, "Entrepreneurial self-efficacy: A systematic review of the literature on its theoretical foundations, measurement, antecedents, and outcomes, and an agenda for future research," J. Vocat. Behav., vol. 110, no. May 2018, pp. 403-419, 2019.

[3] A. Bandura, "Self-Efficacy Mechanism in Human Agency," Am. Psychol., vol. 37, no. 2, pp. 122-147, 1982.

[4] A. Bandura, "The Explanatory and Predictive Scope of Self-Efficacy Theory,” J. Soc. Clin. Psychol., vol. 4, no. 3, pp. 359-373, 1986.

[5] A. D. Stajkovic and F. Luthans, "Self-Efficacy and Work-Related Performance: A Meta-Analysis," Psychol. Bull., vol. 124, no. 2, pp. 240-261, 1998.

[6] C. C. Chen, P. G. Greene, and A. Crick, "Does entrepreneurial self-efficacy distinguish entrepreneurs from managers?,” J. Bus. Ventur., vol. 13, no. 4, pp. 295-316, 1998.

[7] H. Zhao, S. E. Seibert, and G. E. Hills, "The mediating role of self-efficacy in the development of 
[18] E. Gudmundsson, "Guidelines for translating and adapting psychological instruments," Nord. Psychol., vol. 61, no. 2, pp. 29-45, 2009.

[19] E. Cha, K. H. Kim, and J. A. Erlen, "Translation of scales in cross-cultural research: issues and techniques," J. Adv. Nurs., vol. 58, no. 4, pp. 386-395, 2007.

[20] J. W. B. Lang and S. Fries, "A revised 10-item version of the achievement motives scale: Psychometric properties in German-speaking samples," Eur. J. Psychol. Assess., vol. 22, no. 3, pp. 216-224, 2006.

[21] A. N. Husna and N. Akmal, "Validasi Konstruk Skala Karakter Wirausaha," Magelang, 2019.

[10] J. E. Mcgee and M. Peterson, "The Long-Term Impact of Entrepreneurial Self-Efficacy and Entrepreneurial Orientation on Venture Performance," J. Small Bus. Manag., vol. 00, no. 00, pp. 1-18, 2017.

[11] C. Miao, S. Qian, and D. Ma, "The Relationship between Entrepreneurial Self-Efficacy and Firm Performance: A Meta-Analysis of Main and Moderator Effects," J. Small Bus. Manag., vol. 55, no. 1, pp. 87-107, 2017.

[12] J. Schmutzler, V. Andonova, and L. Diaz-Serrano, "How Context Shapes Entrepreneurial Self-Efficacy as a Driver of Entrepreneurial Intentions: A Multilevel Approach," Entrep. Theory Pract., 2018.

[13] A. Bryan, "Pengaruh efikasi diri dan pendidikan terhadap intensi kewirausahaan dengan lingkungan sosial sebagai variabel moderasi," J. Manaj. Bisnis dan Kewirausahaan, vol. 5, no. 3, 2018.

[14] D. Kurnia, Kusnendi, and C. Furqon, "Pengaruh pengetahuan kewirausahaan dan efikasi diri terhadap minat wirausaha," PROMOSI J. Progr. Stud. Pendidik. Ekon., vol. 6, no. 2, pp. 48-56, 2018.

[15] S. C. Susanto, "Pengaruh lingkungan keluarga, pendidikan kewirausahaan, dan efikasi diri terhadap minat berwirausaha mahasiswa," PERFORMA J. Manaj. dan Start-Up Bisnis, vol. 2, no. 3, pp. 277-286, 2017.

[16] J. E. McGee, M. Peterson, S. L. Mueller, and J. M. Sequeira, "Entrepreneurial self-efficacy: Refining the measure," Entrep. Theory Pract., vol. 33, no. 4, pp. 965-988, 2009.

[17] K. F. Geisinger, "Testing and assessment in crosscultural psychology," in Handbook of Psychology Volume 10: Assessment Psychology, J. R. Graham and J. A. Naglieri, Eds. Hoboken, New Jersey: John Wiley \& Sons, 2003, pp. 95-118.
[22] H. Brandstätter, "Personality aspects of entrepreneurship: A look at five meta-analyses," Pers. Individ. Dif., vol. 51, no. 3, pp. 222-230, 2011.

[23] N. Ramdhani, "Adaptasi bahasa dan budaya inventory Big Five,” J. Psikol., vol. 39, no. 2, pp. 189 207, 2012.

[24] E. R. Thompson, "Individual Entrepreneurial Intent: Construct clarification and development of an internationally reliable matric," Entrep. Theory Pract., vol. 33, no. 3, pp. 669-695, 2009.

[25] A. N. Husna, A. A. Zahra, and A. L. A. Haq, "Skala karakter wirausaha (SK - Wira): Konstruksi dan validasi awal," J. Psikol., vol. 17, no. 2, pp. 143-160, 2018 .

[26] R. M. Furr, Scale construction and psychometrics for social and personality psychology. London: SAGE Publications, 2011.

[27] D. Hooper, J. Coughlan, and M. R. Mullen, "Structural Equation Modelling: Guidelines for Determining Model Fit," Electron. J. Bus. Res. Methods, vol. 6, no. 1, pp. 53-60, 2008.

[28] D. A. Kenny, "Measuring Model Fit,” 2015. [Online]. Available: http://davidakenny.net/cm/fit.htm. [Accessed: 17-Jun-2019].

[29] M. J. Austin and M. M. Nauta, "Entrepreneurial Role-Model Exposure, Self-Efficacy, and Women's Entrepreneurial Intentions," J. Career Dev., vol. 43, no. 3, pp. 260-272, 2016.

[30] Z. A. Lope Pihie, "Entrepreneurship as a Career Choice : An Analysis of Entrepreneurial Self-Efficacy and Intention of University Students," Eur. J. Soc. Sci., vol. 9, no. 2, pp. 338-349, 2009. 